\title{
Introvert Senior High School Students' Critical Thinking in Writing Analytical Exposition Text
}

\author{
Muhammad Hasan Affandi ${ }^{1}$ \\ ${ }^{1}$ Corresponding author, English Education Department, STKIP Al Hikmah, Surabaya, Indonesia; \\ hasanaffandi17@gmail.com
}

Received: Desember 20, 2020

Accepted: January 22, 2021

Published: January 22, 2021

\begin{abstract}
This study was carried out to categorize and describe the six aspects of critical thinking in writing analytical exposition text activity toward the introvert senior high school students at the eleventh grade. The aspects were focus, supporting reason, reasoning, organization, convention and integration. The research design was a qualitative descriptive research. This study involved 3 introvert students who have the highest score in selecting the introvert subjects' personality from eleventh grade. The data were divided by two, data for selecting the subject and data for categorizing and describing the critical thinking in writing. First, the data was obtained from questionnaire of MBTI, observation and interview. Second, data was obtained from writing test and interview. The findings in writing analytical exposition text that were assessed toward scoring rubric from (Finken \& Ennis, 1993) that subject 1 and 2 have high critical thinking category. Then, subject 3 has a very high critical thinking category. Every subject has good capacity in six aspects, but the subject 1 and 2 were strong in focus aspect. Subject 3 was strong in focus and reasoning. The subjects were lack in convention and integration aspects.
\end{abstract}

Keywords: Analytical Exposition Text; Critical Thinking; Introvert

To cite this article: Affandi, M. H. (2021). Introvert introvert senior high school students' critical thinking in writing analytical exposition text. SALEE: Study of Applied Linguistics and English Education, 2(01). https://doi.org/10.35961/salee.v2i01.211

DOI: $10.35961 /$ salee.v2i01.211 


\section{Introduction}

People, as social creature who have different personality, need to use the language to communicate each other. They need languages which are used for all communication and being approved. One of them is English, which is considered as one of International languages and has been approved by United Nations.

In line with the condition, people have their own style to communicate each other in thespoken or written way. How they communicate is influenced by their personalities. An expert explains that people's personalities are divided into two types. Jung (1976) in Prakash, Singh, \&Yadav (2016) stated that, "personality is divided into two part, one introvert and second is extrovert. The nature of introvert personality is imaginative, self-centered and idealism".

The researcher specifies study toward introvert students because they are the most minority in the society. It is proven by the statement from Purnomosidi \& Sugiyanto (2015), who stated that the introvert students are the minority inside of the classroom and it is easier to find out extrovert students rather than introvert students.Therefore, the researcher facilitates their thinking into writing activity to communicate their ideas. The researcher will concern in writing activity viewed from introvert students for foreign language classroom. As we know that for measuring the competence specifically, this study focuses on writing skill because writing is a basic skill to communicate and express the information in which it has a society comprehending that it is the activity to communicate meaningfully (Coulson, 2015). Through writing, introvert students have a media to tell the information freely because writing is a route to express the meaning individually (Hyland, 2004). In line with the statement, writing could be a way to state informationand help the students that they have learn something and publishing it through writing.

Delivering information through writing needs thinking process and an understanding process to arrange the words properly. Thus, critical thinking is a way to help introvert students to deliver an information. According to Moon (2008), she states that critical thinking is a deep-thinking process which helps us to understand what may be right or wrong. Beside that the function of critical think is for pay close attention to the argument whether it same of different point of view (zubaidah, 2015). It is analyzing our past experiences and it helps us to resolve situations. Therefore, exploring students' critical thinking is important for embracing and give anopportunity to be developed by students because critical thinking is a thinking process from interpretation till the thinker makes a solution or self-regulation (Yusmin \& Suratman, 1990).

According to the previous research had been conducted by Kuek (2010) in which the researcher developed critical thinking in teaching reading and writing in which there are no explicit guidelines on how they are achieved. Moreover, Binh (2016) made a research regarding about the critical thinking in Vietnamese tertiary English as a foreign language context regarding about the general critical thinking only in the cognitive based on taxonomy bloom. Therefore, the researcher would like to conduct a research about critical thinking through writing for introvert students in thespecific aspect. The researcher focuses on analytical exposition text because the text will give the students media to share information through argument. Hence, the researcher chooses it for introvert students because in the 
analytical exposition text they will be free to share their argument toward topic that is discussed.

So, the aim of this research is to explore what the categories of introvert students' and describes how the introvert senior high school students' critical thinking toward features of critical thinking in writing analytical exposition text are because the researcher wants to promote the introvert students' critical thinking if they have a high critical thinking in writing and gives a recommendation to the English teacher that they can join in the writing competition so that the school will get many achievements from their contribution.

\subsection{Review of literature}

This chapter was arranged by some key words from title. Then, they had been showed shortly in the introduction. They were about introvert, critical thinking, writing theory and analytical exposition text

\subsubsection{Introvert}

The personality of the person is different each other. There are two types of personality that those are contradict. The one relates with show off and high confident, but another one deals with prefer to keep and has many considerations before act. Introvert and extrovert are opposing personalities. The one who identify these personalities is Jung. He describes the introvert deals with the subjective thing. Then, the opposite one is dealing with how the extrovert prefer to the external object from (Helgoe, 2008).

It means, both introvert and extrovert have a different space or area in whichthose are developed by Isabel Briggs Myers a nd Katherine Cook Briggs that is Myers-Briggs Type Indicator (MBTI). MBTI concerns on mapping the personality of introvert in which prefer to inner world, but it has contradiction with extrovert in which prefer to outer world. Then, The Introvert's thinking is concerning to make their selves free or independence. But, for extrovert really love to seek the people as a company (Noman, 2016).

\subsubsection{Critical Thinking}

Talking about critical thinking is difficult to decide the certain definition or comprehension because it is a general term and every people can define what critical thinking by their understanding is. According to Hager et al, (2003), they stated that critical thinking considers into agreement that has been taken on real situation and it is combined by something that was correlated, they are ability and character. It means, critical thinking comes from our life experiences and supported by our intention to analyze an event and effect. In addition, critical think is for pay close attention to the argument whether it same of different point of view (Zubaidah, 2015).

The researcher specifies and focusses the critical thinking term from Finken and Ennis (1993) because this research also concerns in writing essay activity. There are six items, such as focus, supporting reasons, reasoning, organization, conventions and integration. Focus is the first item that it states the topic and covers the sub-topics. The statement is delivered explicitly, and it could be developed by the writer. Second is supporting details. Supporting details is a credibility or as a main resource in which it considers the quality of argument. Supporting detail must provide logical reason so that the reason could be accepted. Third is 
reason. Reason shows the clear explanation to make a conclusion from supporting details. Reason has three components, they are generalizing, best-explanation inferring and value judging. Generalization is concluded from supporting details, best-explanation inferring shows logical reason and it correlates to the topic.

Forth is organization. Organization shows the logical thinking in every paragraph so that it will correlate each other. Organization is not only focus on coherence each of paragraph but also the correlation every sentence. Fifth is convention. Convention is focus on the diction. It standardizes the word based on the context. Sixth is integration. Integration shows the general evaluation to make sure that the written is suitable with the context that it is given. Those are items have scoring criterias from 1 to 6 in which scoring from 1-3 have a meaning "developing" and scoring from 4 to 6 have a meaning "well developed" (Finken \& Ennis, 1993). After scoring each aspect, the researcher categorize their critical thinking from (Sulisworo, 2017)

$$
\text { Value }=\frac{\text { Scorefromindicators }}{\text { MaximumScorefromindicators }} \times 100 \%
$$

Figure 1. Scoring Critical Thinking for Essay Test

Note:

Value: The last score

Score from indicators: The score from write an essay from indicators

Maximum Score from Indicators: 36 (Maximum score for each of aspect is 6)

Table 1. Critical Thinking Categories

\begin{tabular}{ccc} 
No. & Percentages $(\boldsymbol{\%})$ & Category \\
\hline 1. & $81,25<\mathrm{X} \leq 100$ & Very high \\
\hline 2. & $71,50<\mathrm{X} \leq 81,25$ & High \\
\hline 3. & $62,50<\mathrm{X} \leq 71,50$ & Medium \\
\hline
\end{tabular}

(Sulisworo, 2017).

\subsubsection{Writing}

Writing is one of the importance English skills that are needed for students to develop English. Writing is a productive skill (Williams et al, 2005). It means, it is a productive skill in which it will be the last step in English skills because through writing activity the students can produce the product from reading, listening and speaking. Therefore, writing is being the last result after pass the skill before in listening, reading and speaking (Wallace, 2004). Teaching writing can be combined by other skills such as, listening and speaking (Brown, 2001). It means, inside the learning process even the teacher focuses on some skills, such as reading and speaking. But, writing activity will apply automatically. It happens in a speaking activity when the teacher talks about certain topic in the teaching activity, the students will summarize what the teacher talking about through writing. Hence, Writing is importance to 
be focused for students to develop English. In addition, the researcher use an productive approach in this research, not process approach. So, the researcher gets the subjects' wtitten works.

\subsubsection{Analytical Exposition Text}

Analytical exposition text is a one of text that is taught in the senior high school (Eka, P, R. \& Isyam, A, 2013). It consists of arguments dealing with issues or phenomenon that it needs an analysis by the students through their own words how to give an argument with their analysis. An exposition is a kind of text that s concern on presenting a point of view of issue in which has a purpose to persuade the reader or listener to show their argument regarding about issue that it is discussed (Anderson, $\mathrm{M} \&$ Anderson, $\mathrm{K}, 2003$ ). Argumentation is a part tool to communicate relying on reasoning or view, then influences the view by using written or spoken to proof a view or reason (Raybacki, Raybacki, 2004). Therefore, the researcher choose this topic because it gives the students chance to explain their argument toward the issue that had been given by teacher.

\section{Method}

The researcher decides to apply a qualitative research in which focusses on interpretative study. It described the subject using a data that had been take in the research through interview, observing and documenting (Ary et al. 2010). Through that way, the researcher would get the proper way because it would help the researcher to get a valid result. The researcher would describe all the activities while conducting the research. It would help for the next researcher in which would conduct the same research context. The focus of the research was to explore and described the critical thinking of introvert students in writing analytical exposition text. The researcher wanted to know the critical thinking what and how was the introvert students' critical thinking in writing analytical exposition text. Therefore, the researcher used a qualitative basic interpretative approach to explore, analyze and describe all of them clearly or it was called as descriptive qualitative.

The researcher decided to apply a qualitative research in which would be conducted in the eleventh grade at the Private Senior High School of Muhammadiyah 2 Sidoarjo. The researcher chose Senior High School of Muhammadiyah 2 Sidoarjo. The school was one of private school in Sidoarjo in which the school had been accredited "A". The research was started from $1^{\text {st }}$ of April 2018 up to $28^{\text {th }}$ of January 2019. To get the subjects of this research, the research would focus on 3 science classes in which each of class consist about 25 students.

The researcher had some steps to select the subject of this research in which there were 3 subjects that would be concerned in this research because it was different with quantitative research. To take the subjects, the researcher used purposive sampling in which in line with the context that the researcher wanted and need some criterias to select the subjects. So, to select the subjects in research there would be some steps, they were questionnaire, observation and interview. Then, to categorize and describes the critical thinking, the reseracher gave the summary of the data collection in this research and how to explain the process based on the research question through a table:

Table 2. Finding Summary Based on Research Questions 


\begin{tabular}{|c|c|c|c|c|}
\hline No & Question & Aspects & Instrument & Source of Data \\
\hline 1. & $\begin{array}{l}\text { What the } \\
\text { categories of } \\
\text { introvert } \\
\text { sudents' } \\
\text { critical } \\
\text { thinking in } \\
\text { writing } \\
\text { analytical } \\
\text { exposition } \\
\text { text are }\end{array}$ & $\begin{array}{l}6 \text { Aspects Features of } \\
\text { Critical Thinking: } \\
\text { 1. Focus } \\
\text { 2. Supporting } \\
\text { Reason } \\
\text { 3. Reasoning } \\
\text { 4. Organization } \\
\text { 5. Convention } \\
\text { 6. Integration }\end{array}$ & Writing Test & Students' writing text \\
\hline 2. & $\begin{array}{l}\text { How the } \\
\text { introvert } \\
\text { students' } \\
\text { critical } \\
\text { thinking } \\
\text { toward } \\
\text { features of } \\
\text { critical } \\
\text { thinking in } \\
\text { writing } \\
\text { analytical } \\
\text { expostion text } \\
\text { are }\end{array}$ & $\begin{array}{l}6 \text { Aspects Features of } \\
\text { Critical Thinking: } \\
\text { 1. Focus } \\
\text { 2. Supporting } \\
\text { Reason } \\
\text { 3. Reasoning } \\
\text { 4. Organization } \\
\text { 5. Convention } \\
\text { 6. Integration }\end{array}$ & $\begin{array}{l}\text { Students' } \\
\text { Interview } \\
\text { Guideline } \\
\text { (Kuek, 2010 \& } \\
\text { Binh, 2016) }\end{array}$ & $\begin{array}{l}\text { Interview Session toward } \\
\text { subjects }\end{array}$ \\
\hline
\end{tabular}

\section{Finding and Discussion}

The research aimed to describe critical thinking of introvert students in writing analytical exposition text, the data were divided into two parts. First was data for deciding subjects of the research. To select subjects in the research, the researcher had some methods. They were through questionnaire, observation and interview. Second steps was

Table 3. The Highest Score from MBTI Questionnaire

\begin{tabular}{ccc}
\hline No. & Subject & Percentage \\
\hline 1. & Subject 1 & $93 \%$ \\
\hline 2. & Subject 2 & $93 \%$ \\
\hline 3. & Subject 3 & $93 \%$
\end{tabular}

Based on the first research question. It asked about the categories of introvert students' critical thinking in writing analytical exposition text. This question was answered by using scoring rubric from Finken \& Ennis' (1993) and levelling the categories in the next page from Sulisworo (2017). 
Table 4. The Result of Critical Thinking Categories

\begin{tabular}{ccccccc}
\hline \multirow{2}{*}{ No. } & \multirow{2}{*}{ Subjects } & \multicolumn{3}{c}{ Assessment } & \multirow{2}{*}{ Mean } & \multirow{2}{*}{ Categories } \\
\cline { 3 - 5 } & & $\mathbf{A 1}$ & $\mathbf{A 2}$ & $\mathbf{A 3}$ & & \\
\hline 1. & Subject 1 & $72.2 \%$ & $80.5 \%$ & $77.7 \%$ & $77 \%$ & high \\
\hline 2. & Subject 2 & $72.2 \%$ & $80.5 \%$ & $80.5 \%$ & $78 \%$ & high \\
\hline 3. & Subject 3 & $86.1 \%$ & $88.8 \%$ & $88.8 \%$ & $88 \%$ & very high \\
\hline
\end{tabular}

The subjects who had written the essay test were 3 subjects. The topic of the analytical exposition text was given by the teacher who taught an English course. Then, she assessed also by using a scoring rubric that had been provided by the researcher. The researcher looked for another English teacher to assess also the written work of subjects. So, there were 3 assessors who assessed the written work of the subjects.

Second, data for describing the critical thinking of introvert subjects in essay test. Firstly, the researcher took the hand writing of the subjects regarding about analytical exposition text topic. The researcher scored based on Finken \& Ennis (1993) guideline and categorize the critical thinking category from Sulisworo (2017). Then, the researcher interviewed again to the subject to get more information from the subjects toward six aspects of critical thinking in essay test.

In this part, the researcher tried to describe in depth regarding about the hand writing that have been written by the subjects through focus on the first research question. It discussed about the percentages that include deciding the category of critical thinking. Based on the assessor 1 related about the subjects. She gave a percentage for each subject. Subjects 1 and 2 were $72.2 \%$ and subject 3 was $86.1 \%$. Even though the percentages of subject 1 and 2 were same, but there were some aspects in which had a different score. The aspects in which had differences were at organization and convention aspects. In aspect organization, subject 1 was better than subject 1 because she got score 5 and subject 2 got score 4 . Otherwise in aspect convention, the subject 2 was better subject 1 in which he got score 5 in convention aspect. The subject 1 got score 4 only. Different with organization aspect in which focus on the structure, etc. In the convention aspect was bigger domain in which it was focus on the comprehension of the reader about the delivering or convincing of the writer. The subject who was the higher percentage of the other subjects in which she had $86.1 \%$. Based on the six aspects, she had the highest score in some aspects. They were supporting reason, reasoning and integration. Each of score was 5 in which the other score of subject 1 and 2 were 3 and 4 on those three aspects.

The next from assessor 2. Regarding about the percentages. The subject 1 and 2 had same percentages and score for each aspect also. It meant, the researcher focused on the subject 3 directly. She became the highest percentage again among the other subjects. The subject 3 was higher at aspect supporting reason, reasoning and organization in which she got 6 score at supporting reason, reasoning and 5 score at organization. The next from assessor 3. Regarding about the percentages. The subject 3 was being the highest again 
among the other subjects. The subject 1 was the lowest percentage in who had $77.7 \%$ and lower than subject 2 who had $80.5 \%$. Subject 2 was excellent in one aspect, it was a reasoning aspect in which he had score 5 in that aspect. Then, the subject 3 was excellent in some aspect among the other subject2, they were supporting reason, reasoning and organization aspect in which score 5 at supporting reason, organization aspect and score 6 at reasoning aspect. So, the subject 3 would be the highest percentage among the subject 1 and 2 .

\section{Conclusion}

This research was conducted to the second grade of senior high school of Muhammadiyah 2 Sidoarjo. Based on the first research question, the researcher stated that the 3 subjects included in high category critical thinking. In detail, there were 2 introvert subjects who had high category and 1 introvert subject who had very high category critical thinking in writing analytical exposition text. The mean of first subject $77 \%$ and she had high category in critical thinking. Then, the second subject had $78 \%$ and high category in critical thinking. The last subject was third subject. She had $88 \%$ and very high category in critical thinking. So, the 3 students at senior high school of Muhammadiyah 2 Sidoarjo who were being subjects in this research had high category critical thinking.

Second research question was about how the critical thinking of introvert students toward six aspects in writing analytical exposition text. In general, there were six aspects of critical thinking in essay text, focus, supporting reason, reasoning, organization, convention and integration. First, focus aspect reached through looked for the similar issue in which had a correlation with the topic that they wrote about. Second, supporting reason aspect, the subjects reached through took the main idea of issue that they had searched to support the subjects' main idea. Third, the students reached their reasoning through unspontaneusly occured, they made around 5 reasons, but they took some reason only. It happened because they afraid and kept in safe for complaining by others.

Forth they reached organization aspect through re-checked to the other people. They concerned to re-check their writing in sentence structure and others to the other people. Fifth, the subjects reached the convention aspect through understanding of other people because it dealed with comprehension of the text. Sixth, the subjects reached integration aspect through re-check from the first and combined all of the aspect that included on critical thinking in essay test. So, those were the conclusion of second research question of how were the introvert students' critical thinking toward features of critical thinking in writing analytical exposition text. Even this research has been applied, but every research has the strength and weakness that must be considered by the next researcher.

The weakness of this research is very limited on introvert students. The amount of the subjects are 3 introvert students only. It means, even the introvert students are in high category critical thinking, but it could not be as a theory because the subjects who are researched is only 3 . So, it could not become a universal theory because the research is conducted in 1 school only. Furthermore, the researcher wishes for the next researcher to conduct the researcher bigger so that the findings of introvert result could be varieties and could as a theory. 


\section{References}

Anderson, M \& Anderson, K. 2003. Text Types in English 1. Macmillan Education: Australia.

Ary, Donald. Lucy Cheser Jacobs. Christine K. Sorensen. and David A. Walker. 2010.

Introduction to Research in Education.

Binh, N, T, T. 2016. Critical Thinking in a Vietnamese Tertiary English as a Foreign Language Context: University of Technology Sydney.

Brown, H. Douglas. 2001. Teaching by Principles: An Interactive Approach to Language Pedagogy. 2nd Ed. San Francisco: Longman.

Coulson, D. 2015. Focus on Literacy. System, 55, 158-159. https://doi.org/10.1016/j.system.2015.08.006

Eka, P, R. \& Isyam, A. 2013. Teaching Reading an Analytical Exposition Text through Herringbone Technique to Senir Hig School Students. Journal of English Language Teaching, Vol. 2 No. 1, September (289-294).

Finken, M. \& Ennis, R, H. 1993. Illinois Critical Thinking Essay Test. Champaign University.

Hager, P., Sleet, R., Logan, P. and Hooper, M., 2003, Teaching critical thinking in undergraduate science courses. Science and Education, 12 (3), 303-313

Helgoe, L. 2008. INTROVERT POWER: Why Your Inner Life is Your Hidden Strength.

Sourcebooks, Inc: United State of America.

Karyn Charles Rybacki and Donald Jay Rybacki. 2004. Advocacy and opposition, Chapter 8: What should I avoid? Pearson.

Kuek, M, C, T. 2010. Developing Critical Thinking Skills through Integrative Teaching of Reading and Writing in L2 Writing Classroom. University of Newcastle.

Moon, J. 2008. Critical Thinking: An Exploration of Theory and Practice. New York: Routledge.

Murdika, Nafis. 2011. Membaca Kepribadian Menggunakan Tes MBTI (MyerBriggs Type Indicator. 08 Agustus 2018.

https://nafismudrika.wordpress.com/2011/02/18/membaca-kepribadian menggunakantes-mbti-myer-briggs-type-indicator/

Noman, R. 2016. Loud words or Loud Minds: A Qualitative Study about Introverts, 34-38.

Advance Research Journalof Multi-Disciplinary Discoveries: Retrieved from www.journalresearchijf.com.

Prakash, S., Singh, A., \& Yadav, S. K. 2016. Personality (Introvert and Extrovert) and Professional Commitment Effect among B . Ed Teacher Educator Students. The 
International Journal of Indian Psychology, 3(2). Retrieved from http://oaji.net/articles/2016/1170-1453203350.pdf

Purnomosidi, Asep. \& Sugiyanto. 2015. Hubungan Tipe Kepribadian Introvert dan Ekstrovert dengan Perilaku Seks Remaja. Yogyakarta: STIKES AISYIYAH.

Sulisworo, Dwi. 2017. Tingkat Kemampuan Berfikir Kritis Peserta Didik setelah Penerapan Model Pembelajaran Student Team Achievement Divisions (STAD) pada Siswa Sekolah Menengah Atas (SMA). University of Ahmad Dahlan. Retrived from https://www.researchgate.net/publication/318982442 on $4^{\text {th }}$ of August 2018

Wallace, Trudy., et al. 2004. Teaching Speaking, Listening and Writing. International Academy of Education (Educational Practices Series 1- 14).

Williams, Melanie., et al. 2005. The TKT Course. Cambridge: Cambridge University Press.

Yusmin, E., \& Suratman, D. 1990. Kemampuan berpikir kritis ditinjau dari aspek explanation dalam penyelesaian masalah perbandingan di smp, 1-10.

Zubaidah, S. Corebima, AD, Mistianah. 2015. Asesmen Berpikir kritis Terintegrasi Tes Essay.

Malang: University of Malang (200-213). Retrived from https://www.researchgate.net/publication/322315188 in $3^{\text {rd }}$ of August 2018. 